CASE REPORT

\title{
SUDDEN DEATH DUE TO RESPIRATORY TRACT DISEASES
}

\author{
Abdul Gafar Parinduri \\ Faculty of Medicine, University of Muhammadiyah Sumatera Utara, Indonesia \\ Corresponding author: sauqipancasilawati@gmail.com
}

\begin{abstract}
Sudden death is death that occured within 24 hours since of the onset symptoms. Forensic cases, most occur within minutes or even the first seconds of appearance. Sudden death causes can be applied according to the body system, there are central nervous, respiratory, gastrointestinal, haemopoietic, and the endocrine system. Sudden death from respiratory illness is one of the causes of sudden and natural deaths worldwide. Incidence of sudden death in developing countries has a higher frequency. One of the respiratory ailments that causes sudden death is tuberculosis. Case report:a 35 year-old female has been carried out outside examination and in (autopsy) on the corpse. Autopsy was found that lung attachment with chest cavity. Right and left lung was full of foam mixed with pus. This verification supports that the cause of sudden death was due to chonic lung disease.
\end{abstract}

Keywords: Corpse autopsy, pulmonary tuberculosis, sudden death, respiratory disease

\section{INTRODUCTION}

The death that occurs suddenly can be found in all conditions. Death can occur when people are exercising, active or resting. Sudden death itself is actually not always a sudden process, even actually sudden death is an end of the disease that the victim has suddenly died. Sudden death caused by disease, often brings suspicion to investigators and the general public, especially if the death befalls on someone known in the community. ${ }^{1}$

In general, the cause of sudden death is due to disease. Diseases that can cause sudden death are divided into several categories, namely the cardiovascular system, respiratory system, central nervous system, gastrointestinal system, and urogenital system. ${ }^{2,3}$

Post-mortem study data taken at Connoly Hospital in Dublin in 1987December 2001 stated that the most sudden death occurred due to heart disease by $79 \%$. Data in Indonesia shows that sudden death in men is occurring frequently compare than women. In 1990 it was found with 227 men $(81.90 \%)$ and 50 women $(18.05 \%)$, while in 1991 there were found 228 men $(80.85 \%)$ and 54 women $(19.14 \%){ }^{1,2}$

The respiratory system also contributes to sudden death. Death from the respiratory system can occur due to respiratory tract bleeding, asphyxia, and pneumothorax. Bleeding can occur due to tuberculosis (TB) which is the most 
common cause of death in developing countries. Whereas asphyxia can occur in bronchial asthma, bronchiectasis, and diphtheria which can also cause sudden death from the respiratory system. ${ }^{4}$

Tuberculosis is one of ten diseases that cause the largest mortality rate in the world, whereas in Indonesia TB is the second leading cause of death after a stroke at the age of 15 years and above and also causes of death in infants and toddlers. ${ }^{5}$

\section{CASE REPORT}

The female body, aged \pm 35 years, was delivered to the hospital forensic room. On examination found a body length of $155 \mathrm{~cm}$, brown skin color, characterized by short hair and curls, thin stature.

Labels, corpse wrappings, corpse covers, corpse jewelry and objects beside the bodies were missing, the red corpse shirt was not collared with a picture of a doll without a brand, wearing brown-gray shorts without a brand and size. Signs of death are found: 1) Body mortar: on the back, waist, and buttocks that are not lost on emphasis. 2) Rigid bodies: Found in the joints of the jaw, neck, upper limbs and lower limbs, which are easily resisted, 3) Decay: Not found.

\section{External examination}

At the head examination, hair is short, curly and not easily removed, the hair length is twelve centimeters in front, the back is five centimeters, the right and left sides are ten centimeters. On touching there are no signs of fracture. In the eyes, the two inner eyelids appear pale and the two eyeballs are cloudy. Forehead, nose, ears, cheeks, and mouth no signs of violence. Teeth number fourteen, incomplete and rarely arranged. In the jaw, neck, shoulders, chest, abdomen, back, waist, hips, buttocks, and anus there are no signs of violence. Female gender, no signs of violence were found. Members of the upper and lower limbs are not found signs of violence and are found bluish fingertips.

\section{Internal examination}

On examination in the opening of the scalp, there are no signs of violence. Found closure of the head bone (S3 obliteration). At the opening of the skull, the blood is not found. At the opening of a thick membrane, the brain is found to expand brain blood vessels. At the opening of the thin membrane of the brain, no blood absorption is found. At the incision of the cerebrum, the cerebellum, the brain stem is not seen bleeding spots. The brain weight is one thousand two hundred grams. There was no fracture of the skull base. At the opening of the neck, the skin is not found blood absorption in the skin of the inner neck, the opening of blood vessels in the neck are not found signs of violence.

At the opening of the upper respiratory tract blood fluid mixed with fine foam is difficult to break. At the opening of the chest skin, no signs of violence and thickness of chest fat were found at zero point three centimeters. Lung adhesions in the lungs are found with the chest wall from 1 to 3 ribs. The right lung weight is four hundred fifty grams. Chewy consistency, blackish brown surface, on slicing the lungs found smooth froth mixed with pus. The weight of the left lung is four hundred grams. The consistency of chewy lungs, the surface is blackish brown, in the pulmonary incision a fine foam mixed with pus is found. At the opening of the heart bag, a clear yellow liquid is found, the surface of the pale heart muscle is 
found, there are three leaf valves, valves of the pulmonary arteries, valves of two leaves, valvular valves of the heart are not found abnormalities.

In the upper feeding cannot be found food scraps and blood fluids. Thick belly fat is zero point three centimeters. At the opening of the stomach, no food remains. No blood infiltration is found in the intestinal hanger. The surface of the intestine is pale, there are no signs of violence. On examination of the liver found a slippery surface, consistency of solid, brownish red color, no signs of violence were found. The gallbladder is not seen as a sign of violence. The lymph surface wrinkles brownish red, no signs of violence are found. The right kidney capsule is easily removed, no signs of violence are found. The left kidney capsule is easily removed, there are no signs of violence. There were no signs of violence in the hip cavity.

\section{DISCUSSION}

External examinations were not found to show signs of violence. Whereas in the inner examination, there was sticking of the left lung with the wall of the chest cavity from ribs 1 to ribs 5, found lung surface blackish brown, chewy consistency, on examination found soft foam and pus. Based on the results of the autopsy, the body was declared dead because of suffocation due to chronic lung disease he suffered.

Sudden death due to respiratory disease is one of the causes of sudden and natural death throughout the world, the frequency in developing and underdeveloped countries is still much more. A retrospective study was conducted at the center at Kasturba Medical College, Mangalore, in cases accompanied by a history of sudden death in order to study the causes of death from respiratory system disease. Of the 2,515 autopsies performed 274 (10.89\%) were sudden deaths, of which $81(29.56 \%)$ were caused by respiratory system related diseases. ${ }^{6}$

Tuberculosis is a contagious infectious disease caused by Mycobacterium tuberculosis. WHO data is that there are 10-12 million pulmonary TB sufferers who are capable of transmitting. The death rate reaches three million per year. The spread generally exists in developing countries with low socioeconomic conditions. Indonesia TB is the second leading cause of death after a stroke at the age of 15 years and over and causes of death in infants and toddlers. ${ }^{5}$

Widespread pulmonary tuberculosis in the patient's body can be through various ways: (1) Spread of percontinuitatum or directly to the surrounding tissue (2) Spread through the airways (3) Spread through lymph channels (pleura, backbone and thorax wall) (4) Hematogenous spread. Clinical features associated with pulmonary $\mathrm{TB}$ and often are productive long coughs (duration of more than 3 weeks), chest pain and hemoptysis. The cause of death in pulmonary TB infection is massive hemoptysis from the tuberculosis caverns. At the lung autopsy, the caverns will be found which is marked by pus discharge when the lung is massaged. ${ }^{7}$

Pulmonary adhesions can occur due to chronic pulmonary disease, one of which is pulmonary tuberculosis. ${ }^{8,9}$ Histopathological examination was not carried out on this body because there was no adequate cost. Medicolegal aspects. The need for inspection in cases of sudden death is to get rid of any criminal actions. In criminal actions, the perpetrator will usually take an action or business so that the crime is not known 
by others, either by the family, community or the police.

\section{CONCLUSION}

Based on the findings of the examination of the corpse, it was concluded that the cause of death of the victim was due to suffocation due to chronic lung disease he suffered.

\section{REFERENCE}

1. Govan ADT, MacFarlane PS, Callander R. Respiratory system in: pathology illustrated. New York: Longman Group (FE) Ltd. 1998. p299 $-378$.

2. Suryadi T. Kematian mendadak. Jurnal Kedokteran Syiah Kuala, Agustus 2017. 17 (2):112-118.

3. Mutahan, Apuranto H. Kematian mendadak dalam Buku Ajar Ilmu Kedokteran Forensik dan Medikolegal. Edisi 7, 2010. Fakultas Kedokteran Universitas Airlangga Surabaya.

4. Novita N. Peran pemeriksaan histopatologi dalam otopsi: Studi Kasus Jenazah Mati Mendadak. 2017, ISBN 978-602-50127-0-9

5. Kementerian kesehatan Republik Indonesia. InfoDATIN: Tuberkulosis. Jakarta, 2016.

6. Shah PA, Gamit B, Dalal C, Shah P. Pattern of mortality in sudden Death: an autopsy study. 2017. Int $J$ of Community Med Public Health. 4: 792-6.

7. Dimaio VJM, Dana SE. Respiratory system in: handbook of forensic pathology.2002. Landes Bioscience. Texas. p51 - 54.

8. Rastogi, Prateek, Acharya, Jenash. A study of respiratory system related causes of sudden death. 2013. Indian
Journal Of Forensic Medicine And Toxicology, 11 (4). h. 87-89.

9. Ratih Oemiati. Kajian epidemiologis penyakit paru obstruktif kronik (PPOK). Juni 2013. Media Litbangkes Vol. 23 No. 2,: 82-88. Jakarta: Pusat Teknologi Intervensi Kesehatan Masyarakat Badan Penelitian dan Pengembangan Kesehatan, Kementerian Kesehatan RI 